História (São Paulo)

\title{
O mundo americano na produção escrita inglesa: séculos XVI, XVII e XVIII
}

\section{The american world in the english written production: XVI, XVII and XVIII centuries}

Lílian Martins de LIMA ${ }^{\bullet}$

Resumo: A apreciação do Novo Mundo por letrados ingleses, irlandeses e escoceses pode ser pontuada a partir da segunda metade do século XVI. A compreensão acerca dessa temática é um dos eixos deste artigo, que pretende avaliar as nuances da produção escrita em língua inglesa entre os séculos XVI, XVII e XVIII, com destaque para a formulação de histórias filosóficas da América. Buscamos, em linhas gerais, avaliar de que forma o cenário americano foi descrito por autores que, em diferentes momentos, se indagaram sobre o lugar da América na historiografia inglesa.

Palavras-chaves: Historiografia Inglesa, América, William Robertson, Histórias Filosóficas.

Abstract: The appreciation of the New World by english, irish and scottish authors can be noted since the second half of the sixteenth century. The understanding of this theme is one of the goals of this article that seeks to evaluate the written production between the sixteenth, seventeenth and eighteenth centuries, with emphasis on the formulation of philosophical histories of America. We pretend, in short, evaluate how the american scenario was described by authors that, in distinct moments, have asked about the place of America in the english historiography.

Keywords: English historiography, America, William Robertson, Philosophical Histories.

O surgimento de uma produção escrita, em língua inglesa, acerca dos territórios do Novo Mundo data da segunda metade do século dezesseis. A partir de 1550, segundo J. H. Elliot, podemse mapear os tímidos, mas constantes, esforços que, no decorrer do período elisabetano, deram origem - na forma de relatos de viagem, panfletos, panegíricos, poemas, etc. - a um conjunto de escritos voltados não somente a descrever o cenário americano, mas também a avaliar suas potencialidades. ${ }^{1}$

Depois das primeiras divulgações das terras incógnitas - feitas principalmente por portugueses, espanhóis e italianos -, corsários, viajantes, mercadores e aventureiros ingleses começaram a divulgar suas impressões sobre o evento, que era saudado com entusiasmo por alguns e visto com receio por outros. Tal lentidão no processo de incorporação do cenário americano pelos ingleses - se comparado ao processo espanhol, por exemplo - pode ser compreendida se levarmos

\footnotetext{
•Doutora em História - Email: lilian.ml10@yahoo.com.br.
} 
em conta, entre outros fatores, a inicial resistência dos ingleses em participar da aventura colonial, ou melhor, a hesitação em investir grandes somas num empreendimento que suscitava muitas dúvidas quanto às suas potencialidades de lucro.

Mas, apesar de disperso e discreto, o impacto dos territórios do Novo Mundo fez-se presente entre os súditos do reino inglês. Inicialmente, breves menções atentam para a existência de novas terras repletas de seres e condições fantasiosas; aos poucos, o cenário americano divulgado nas páginas de inúmeros viajantes, missionários e curiosos ganha sobriedade e passa a impulsionar a realização de diversos projetos de viagens marítimas - que, no caso inglês, ganham corpo com as viagens de Giovanni Caboto, Martin Frobisher e Walter Raleigh.

A produção escrita levada a cabo nesse período é a responsável não somente pela apresentação do Novo Mundo ao público inglês como também pela promoção da participação deste Novo Mundo nos negócios de além-mar. Tal característica é marcante nessa produção, que tem a missão de tornar familiar um mundo até aquele momento desconhecido. $\mathrm{Na}$ tentativa de fornecer o maior número possível de informações e dados geográficos sobre a "América", esses textos são ricos na descrição das condições climáticas, da fauna e flora encontradas, dos nativos e das possibilidades de comércio de artigos como peixes, frutas, etc. É interessante notar aqui que a menção à possível descoberta de metais é esparsamente relatada e tende, com o passar dos anos notadamente no século XVII -, a perder espaço para uma narrativa na qual a listagem das commodities a serem comercializadas e os procedimentos e incentivos para uma ocupação efetiva do Novo Mundo são predominantes. ${ }^{2}$

O primeiro passo nesse processo é dado com a viagem de Giovanni Caboto, apontada já no século XVI pelo editor de relatos de viagem Richard Hakluyt como o marco inicial da participação inglesa na aventura em terras do Novo Mundo. Mercador de origem genovesa, Caboto realiza uma série de viagens em 1497 para a região conhecida como Newfoundland ${ }^{3}$, a serviço do rei da Inglaterra, com o intuito de descobrir uma passagem para o oeste que permitisse uma comunicação mais eficaz dos mercadores ingleses com as Índias Orientais.

Entre as primeiras traduções de escritos acerca do Novo Mundo vertidas para o inglês, cabe destacar a figura de Richard Éden, responsável pela tradução da obra Decades of the New World, de Peter Martyr, em 1555. Nela, além dos comentários sobre as potencialidades físicas das novas terras, o autor salienta a urgência da ocupação de imensos territórios, ainda desprovidos de uma população cristã. 
Uma coisa que vejo e considero necessário falar e lamentar: a colheita é tão grande e os trabalhadores são poucos. Os espanhóis tem mostrado um bom exemplo para todas as nações cristãs. Mas como Deus é tão grande e maravilhoso em toda a sua obra, além da porção de terra pertencente aos espanhóis, sendo oito vezes maior do que a Itália [...], e além do que pertence ao reino português, ainda resta uma outra parte deste continente em direção ao oeste, tão grande quanto às outras partes, conhecido apenas pela costa do mar e não habitado por nenhum homem cristão. (EDEN apud JEHLEN, 1997, p. 50).

Já em 1576, Martin Frobisher, interessado em encontrar uma passagem a noroeste para a China, realiza duas viagens cujas agruras e as impressões sobre os habitantes encontrados são descritas por Christopher Hall. $\mathrm{Na}$ viagem realizada no ano seguinte, Frobisher reavalia as dimensões físicas da região, especialmente o clima, que aparenta ser mais temperado, e uma extensa faixa de água, que sugere uma dimensão maior do que a imaginada para aqueles territórios.

Outra personagem notável nessa aventura inglesa foi Sir Humphrey Gilbert que, em 1578, após receber da rainha uma carta patente que concedia a autorização para "descobrir, encontrar, procurar em remotas, pagãs e bárbaras terras, regiões e territórios ainda não tomados por algum príncipe ou povo cristão", realiza duas viagens (das quais só temos conhecimento da última, realizada em 1583, pelas anotações de Edward Hayes) que deram origem ao livro Voyage to Newfoundland. Esse relato atenta primeiramente para a legitimidade da empreitada, uma vez que a região havia sido descoberta por Giovanni Caboto a serviço do reino inglês. ${ }^{4}$ Em seguida, destaca as inúmeras riquezas lá encontradas - como madeira, peixes, entre outras - e a ausência de habitantes ou a presença de selvagens mansos. Tais descrições, esperava-se, uma vez divulgadas entre o público inglês, deveriam estimular a participação nos negócios de ultramar.

No sul não encontramos habitantes, os quais provavelmente abandonaram essas costas, tão freqüentadas por cristãos, porém no norte os selvagens são completamente inofensivos. No que diz respeito aos produtos dessa região servem tanto para o sustento dos habitantes ou para o tráfico, há muitos e diversos, parece que a natureza recompensou o frio acentuado com muitos benefícios, nomeadamente com uma inacreditável quantidade e não menor a variedade de peixes de mar e de água doce, como trutas, salmões e outros peixes por nós desconhecidos[...]. Não foi possível observar a centésima parte dos animais nessas terras desabitadas mas esses podem induzir-nos a glorificar o magnífico Deus que tem abundantemente provido a terra com animais a serviço do homem, embora esses não tenham usado nem a quinta parte [...]. O que tem agravado [essa situação] é uma tola preguiça em muitos de nosso reino, ao preferir viver indiretamente e de forma miserável do que se aventurar para conseguir uma 
habitação nessas terras remotas nas quais a natureza muito prodigiosamente age. (GILBERT, 1910, p. 59).

Em outro texto, Gilbert apresenta a posse desses territórios como algo que representava "um grande avanço para nosso reino, uma possibilidade maravilhosa de enriquecimento com indizíveis commodities para todos os habitantes da Europa".

[...] encontraram o mesmo clima temperado, um pouco mais quente do que a Inglaterra nessa época do ano, repleto de peixes de diferentes sortes, tanto de água salgada como de água doce [...] que poderia ser suficiente para um exército. As viagens empreendidas recentemente para o comércio e o estabelecimento de colonos na América é uma ação que tende ao alargamento dos domínios legais de sua Majestade, cômodo para todo o Reino em geral, rentável aos aventureiros em particular, benéfica aos selvagens e uma matéria a ser executada sem grande perigo ou dificuldade. E, finalmente, acima de tudo, algo que tende igualmente à honra e glória de Todo Poderoso Deus. (GILBERT, 1910, p. 121).

Como se vê, todo o reino seria beneficiado, mas para tanto não bastava apenas conhecer as condições físicas da América, era preciso, efetivamente, ocupá-la, colonizá-la. Anos mais tarde, em 1595, o meio irmão de Gilbert, Sir Walter Raleigh, realiza uma viagem para a Guiana ${ }^{5}$ que resulta num relato intitulado The Discovery of the large, rich, and beautiful Empire of Guiana. Raleigh, conhecido por ser um dos favorecidos durante o reinado de Elizabeth, procura se defender das acusações de traição ${ }^{6}$ e elucida todo seu empenho em encontrar o chamado El Dorado, uma região rica em metais preciosos, prometendo à rainha a posse de um império tão lucrativo quanto as possessões espanholas no México e no Peru.

Até esse momento, deparamo-nos com breves e esparsas anotações e relatos de viagem que procuram descrever os aspectos físicos, tais como o clima, a hidrografia, a fauna, etc. do Novo Mundo e que chamam a atenção para as imensas e satisfatórias possibilidades de exploração e de ocupação do território por súditos do reino inglês. Nesse processo, coube a Richard Hakluyt o esforço de sistematizar de que forma os ingleses deveriam efetivamente proceder. Não por acaso, na história da atuação inglesa no Novo Mundo a figura do editor Richard Hakluyt ocupa um lugar central. Altamente empenhado em promover entre os ingleses o interesse por novos territórios, Hakluyt redige, em 1584, o Discourse of the western plantation, texto no qual salienta as imensas e ricas oportunidades que o Novo Mundo oferecia - desde condições naturais favoráveis para uma 
vida mais saudável até os inúmeros produtos cuja comercialização prometia rendimentos consideráveis. Ao longo de mais de vinte sessões, Hakluyt lista o extenso rol de produtos cuja comercialização indicava uma nova alternativa para os mercadores ingleses, preocupados que estavam com a concorrência dos franceses e espanhóis. Além dessas vantagens, o editor inglês destaca ainda duas razões de interesse na colonização das novas terras: a expansão da fé protestante e a urgente necessidade de o reino inglês rivalizar com a Espanha o comando dos territórios do Novo Mundo.

[...] por quais meios e por quem o mais bondoso e cristão trabalho pode ser realizado para difundir o glorioso evangelho de Cristo e reduzir a multidão desse povo simples que estão no erro para dentro do correto e perfeito estado de salvação [?]. [...]. Então é necessário para a salvação desses pobres povos que durante tanto tempo estiveram na escuridão e na sombra da morte que pregadores sejam enviados à eles. [...]. A América clama para que seus vizinhos próximos venham, ajudem $\mathrm{e}$ tragam à eles o evangelho. (HAKLUYT, 1877, p. 11).

Quanto à concretização da ideia da superioridade inglesa frente aos rivais espanhóis, Hakluyt enfatiza as inúmeras vantagens de seu reino, com destaque para sua longa tradição na empreitada marítima, uma vez que, 300 anos antes de Colombo, navegadores ingleses já conheciam o território que, séculos mais tarde, seria denominado América; ou seja, longe de ser ilegal, a presença inglesa ali era legítima.

Nós da Inglaterra temos mostrado antigas e autênticas crônicas escritas em galês ou em língua britânica [...]. Nós fizemos duas viagens fora de Gales e descobrimos extensas regiões que encontramos a sudoeste da Irlanda no ano de nosso senhor 1170. E isso foi confirmado pelo idioma de alguns povos do continente entre a baía do México e a grande baía de Newfoundland, cujo idioma é semelhante ao gaulês em diversas palavras assim como os nomes de lugares, [o que evidencia] que alguns de nosso reino estiveram nessas partes. Por esse testemunho, parece que as Índias Ocidentais foram descobertas e desabitadas 322 anos antes de Colombo fazer sua primeira viagem que ocorreu no ano de 1492 [...]. (HAKLUYT, 1877, p. 15).

Hakluyt não é o único a reivindicar um suposto pioneirismo inglês nas viagens marítimas. No entanto, coube a ele a redação de uma obra que apresentava um projeto de ocupação inglesa nas terras do Novo Mundo. Sua preocupação com o avanço e as fortunas adquiridas por mercadores e viajantes para a Coroa espanhola o faz esboçar uma trajetória de ação que possibilitaria reverter 
esse cenário para o lado inglês. Contudo, Hakluyt precisaria, antes de tudo, vencer a apatia dos seus compatriotas nesse processo.

Além do apego a uma suposta "tradição" inglesa nos negócios em alto mar, Richard Hakluyt aponta algumas deficiências da administração espanhola em suas possessões americanas - como a ausência de fortificações e de qualquer aparato defensivo -, possessões que deveriam ser exploradas pelos ingleses, afinal, "se tomarmos as Índias [Ocidentais], nos apoderamos da menina dos olhos [dos espanhóis]." Nesse sentido, a fragilidade defensiva espanhola somada à tradição dos ingleses fornecia um cenário cada vez mais favorável para esses últimos que, no parecer de Hakluyt, estavam destinados a assumir um lugar de destaque no Novo Mundo. Com um cenário profícuo, Hakluyt não compreendia o porquê da relutância inglesa em investir nos territórios do Novo Mundo. Daí, por certo, o tom de urgência do seu Discourse, no qual cobra mais ação por parte dos ingleses.

[...] Antes de mais nada, nessa matéria de grande importância e de grande ganho para um príncipe estrangeiro, a única coisa a fazer é estabelecer colônias e fortificações. [...] Se nós protelarmos o estabelecimento de uma colônia (e onde nossos homens descobriram e encontraram a melhor parte da América, e na verdade, a mais agradável e mais próxima da Nova Hispânia), os franceses, os normandos, os bretões ou os holandeses ou algum outro reino não irão evitar; talvez na Baia de São Lourenço onde eles já conhecem, na qual foi-nos revelado por livros publicados e impressos em inglês antes deles[...]. (HAKLUYT,1877, p. 75).

A crença nas extraordinárias oportunidades que o estabelecimento de colonos oferecia para a expansão da fé e para o fortalecimento do reino inglês perpassa toda a produção escrita do período. Ao comparar os estabelecimentos espanhóis e portugueses, o editor inglês é enfático acerca das possibilidades de êxito dos súditos de Elisabeth, afinal "se eles [espanhóis], na sua superstição, fizeram tão grandes coisas em suas colônias em tão curto espaço, o que podemos esperar em nossa verdadeira e sincera religião?” (HAKLUYT apud MANCALL,2007, p. 140). Após relatar de forma detalhada todos os passos necessários para garantir o sucesso da empreitada - a vinda e o estabelecimento de colonos, associados às trocas comerciais de produtos entre o Novo e o Velho Mundo - e listar as vantagens decorrentes dessa posse, Hakluyt destaca que o estabelecimento colonial estava aberto a todos os ingleses, que nas suas diversas ocupações seriam os protagonistas dessa elevada missão de "estabelecer uma sincera religião e prover um lugar seguro para receber 
pessoas de todas as partes do mundo que foram forçadas a fugir pela verdade da palavra de Deus". (HAKLUYT,1877, p. 82).

Além da redação do Discourse - inédito até sua publicação na segunda metade do século XIX, em 1877 - Hakluyt dedicou-se àquela que seria sua mais conhecida obra, The Principal Navigations, Voyages, Traffiques and Discoveries of the English Nation, uma coletânea de narrativas de viagem composta por três volumes, publicada pela primeira vez em 1589 . Dedicada a Robert Cecil, a obra apresenta uma série de narrativas que destacam o empenho inglês nas navegações, desde as viagens de Giovanni Caboto até as aventuras de Francis Drake, passando pelas iniciativas de Martin Frobisher com o intuito de encontrar uma passagem para o noroeste; em outras palavras, o editor inglês apresentava a seus leitores uma espécie de histórico da participação inglesa nas viagens de descobertas na qual advoga a propensão natural dos ingleses para o Novo Mundo. Relatos de Sir Humphrey Gilbert, Martin Frobisher, entre outros, dividem espaço com trechos de cronistas espanhóis, como Gômara, Oviedo e Antonio de Mendoza.

Mais do que coletar, traduzir e divulgar uma série de narrativas de viagem, Richard Hakluyt buscou promover entre os ingleses o desejo de investir no Novo Mundo, pautando-se, sobretudo, por uma suposta longa tradição em viagens marítimas dos ingleses, na necessidade de propagar a fé e na expansão e soberania do reino. Tal desejo permanece com a publicação em 1625 de outra grande coleção de relatos de viagem, dessa vez sob o comando de Samuel Purchas. Intitulada Hakluytus Posthumus or Purchas his Pilgrimes; Contayning a History of the World, in Sea Voyages and Land Travels, by Englishmen and Others, a obra, cuja primeira edição se dividia em quatro volumes, reúne inúmeros relatos que, assim como na obra de Hakluyt, abordam as mais diversas regiões exploradas por diferentes povos europeus. Baseando-se nos relatos legados por tripulantes das viagens de Caboto, Purchas, do mesmo modo que Richard Hakluyt, dedica-se a documentar e divulgar o pioneirismo e, principalmente, a legalidade da posse e ocupação das terras americanas pelos súditos do reino inglês, além de mencionar as possibilidades de enriquecimento que essas viagens proporcionavam.

Tais argumentos fizeram eco em toda a produção escrita inglesa do século XVII interessada em relatar, entre o público, as primeiras experiências coloniais do reino, como é o caso da narrativa de John Smith, fundador da Virgínia. Publicada em 1608, A true relation of such occurences and accidents of note as hath happened in Virginia descreve as agruras dos primeiros 
contatos com os nativos, mas alerta, em seu parecer final, sobre as possibilidades de êxito, notadamente comercial, oferecidas pelas colônias.

Estando agora com boa saúde e desejando uma contínua paz com os indígenas, não duvidamos da amável assistência de Deus em tão honorável ação, e tempos depois veremos nosso reino desfrutando nessa região, não apenas de agradáveis habitações, mas também de um proveitoso comércio em geral, sem dúvida satisfazendo o onipotente Senhor, honroso da soberania de todo o reino. (SMITH,1866, p. 78).

Como vimos até aqui, houve todo um esforço na divulgação das vantagens abertas pelo Novo Mundo que visava, em última instância, a superar a apatia inglesa e impulsionar o reino a assumir um lugar de destaque entre as Coroas europeias que participavam do empreendimento colonial. Nesse sentido, a atuação de associações como a Virginia Company, uma companhia de promoção da colonização junto ao público inglês, é exemplar. Responsável por angariar colonos para as possessões inglesas no Novo Mundo, os textos divulgados pela Virginia Company procuraram rechaçar os rumores e as calúnias que envolviam o empreendimento colonizador. Tendo entre os seus membros figuras eminentes como John Hawkins, Richard Hakluyt, John Smith, entre outros, a companhia publicou, em 1620, A Declaration of the state of the colonie and affaires in Virginia, texto no qual procura responder aos "falsos e maliciosos rumores acerca das condições naturais, dos habitantes e do desenvolvimento da colônia".

Divulgadas especialmente em peças teatrais, as informações que a companhia procurava desmentir apontavam para as escassas possibilidades de lucro - identificado aqui com a inexistência de descoberta de ouro e prata -, para a brutalidade dos habitantes nativos e para as rigorosas condições climáticas da colônia. Anos antes, em 1610, a companhia publicara A true and sincere declaration of the purposes and ends of the plantation begun in Virginia, texto no qual atenta para o fato de que o estabelecimento de colonos no Novo Mundo não representava apenas um importante negócio para o comércio inglês, mas também constituía um passo mais do que necessário para o fortalecimento de todo o reino.

Tal perspectiva é compartilhada por Robert Gray que, em 1609, redige A Good Speed to Virginia, trabalho no qual declara aos que se punham contra a colonização que "toda oposição é uma oposição à Deus, ao Rei, à Igreja e à Commonwealth" uma vez que Deus ofereceu aos ingleses a possibilidade de expandirem a verdadeira fé e de protagonizarem um dos mais edificantes 
e gloriosos episódios da história da humanidade. Também em resposta aos "difamadores da colonização", o texto de 1609 atenta para as inúmeras riquezas do território. Além de enfatizar o clima agradável e o enorme potencial de sucesso dos colonos nessas terras, o autor salienta que "[...] essa é uma região que nada, a não ser a ignorância e uma mente corrupta, pode difamar". (GRAY, 2008, s.p.).

Diante de tantas críticas à colonização no Novo Mundo, considerado por muitos uma aventura inútil, os relatos da Virginia Company procuravam, em resumo, convencer o público inglês das vantagens e do caráter honroso da colonização - nas palavras do conselho, "uma nobre ação de colonizar a Virgínia com uma religião cristã e com a participação do povo inglês”. Para arrematar, na trilha das observações de Richard Hakluyt, o texto lista uma variedade de profissões, desde marceneiros até vinicultores, cujas ocupações no Novo Mundo eram bem-vindas. Porém, apesar do esforço da Companhia e de seus membros, a desconfiança e a hesitação inglesa sobre o Novo Mundo perdurou por muito tempo, a ponto de, em 1705, Robert Berkeley, autor de History and Present State of Virginia ver-se obrigado a tentar calar tais boatos.

Ouvi dizer que este país é criticado pelas mudanças bruscas e perigosas do clima, mas tal acusação é injusta, pois na verdade, os ventos são brisas frescas e agradáveis, que servem para refrescar o ar, e corrigir os excessos de calor [...]. (BERKELEY,1705, p. 251).

A avaliação dos primeiros resultados oscila, como notou Catherine Amstrong, entre a celebração dos avanços e a constatação dos limites destes. A descrição dos atrativos físicos desses territórios agora divide espaço com a análise dos melhoramentos alcançados e dos obstáculos a serem superados, obstáculos quase sempre identificados com a presença indígena. Boa parte dessa produção escrita dedica-se a listar os avanços obtidos e o papel crucial exercido pelos colonos nesse momento. Ao percorrer esses textos, chama atenção a predominância do vocábulo improvement nos relatos, comentários, panfletos, cartas, sermões, histórias, etc. Esse vocábulo é central nessa produção escrita; narrar a atuação inglesa é listar e expor os melhoramentos feitos nessa paisagem; são tais avanços que possibilitaram superar o estado selvagem do território, que se encontrava abandonado por seus habitantes nativos. Logo, ao propiciar o improvement dessas terras, os súditos ingleses fazem um uso legal e legítimo delas: eis aqui uma importante premissa para compreendermos a construção dessa interpretação inglesa do Novo Mundo, fortemente apoiada na 
ideia de legalidade. Afinal, se os silvícolas não fizeram o efetivo "bom uso" dessas regiões, os ingleses tinham todo o direito de fazê-lo. Num tom praticamente uníssono, essa é a argumentação que, desde o século XVI, se faz presente no discurso inglês e que se manterá até a formulação das chamadas "histórias da América", no século XVIII.

Não devemos nos esquecer de que, em sua maioria, esses discursos foram redigidos por colonos que exerceram importantes funções na administração dos territórios, como foram os casos de William Bradfod e William Hubbard. O primeiro desempenhou o cargo de governador durante 35 anos em Plymounth, na baía de Massachussets, e em seu relato, intitulado History of Plymouth Plantation (1646), avalia anualmente os progressos ocorridos na colônia, com destaque para a conversão dos indígenas e para a superação de inúmeras adversidades naturais, como as baixas temperaturas e a presença de diversos animais selvagens. Ao evidenciar essas conquistas, o autor não deixa de mencionar que, orientados os colonos por tão nobre ideal, o êxito inglês deveria ser mais do que esperado.

[...] todas as grandes e honrosas ações são acompanhadas de grandes dificuldades, e ambas iniciativas devem ser respondidas com coragem. Os perigos são grandes mas não desesperadores; as dificuldades são muitas mas não invencíveis [...]. E todos eles [os colonos] com a ajuda de Deus, com firmeza e paciência. [...] podem esperar pela benção de Deus nesse processo. (BRADFORD, 1908, p. 176).

Ao longo da produção escrita legada por colonos e viajantes dos séculos XVI e XVII é possível perceber a recorrência de excertos como o apresentado acima, nos quais a percepção dos territórios americanos passa pela crença concomitante em ao menos dois outros aspectos: o de que a região é desabitada e, portanto, “aberta" para aqueles que estejam dispostos a promover melhoramentos; e a de que, uma vez em tais territórios, a probabilidade de enriquecimento é quase certa. Essas duas características somadas a outras são, de acordo com as análises do historiador Jack Greene, as responsáveis por fundar este traço crucial para a historiografia do século XIX de matriz norte americana. ${ }^{7}$

Os modestos resultados da conversão dos indígenas, por sua vez, evidenciavam o grande obstáculo à colonização apontado pelos colonos. De acordo com William Hubbard, autor da $A$ General History of New England, de 1650, os resultados até então eram modestos, afinal, "Nossa religião, pouco entre eles parecem ter seriamente abraçado-a, mas enquanto não forem reduzidos à 
civilidade algumas pessoas ponderam que não seja esperado grandes conversões [visto] o pequeno progresso feito no presente [...]. (HUBBARD,1848, s.p).

Se, por um lado, os ingleses conheciam o fracasso no que tange à evangelização dos silvícolas, por outro, o mesmo não pode ser aplicado às lavouras de cana de açúcar ou ao cultivo de tabaco, isso já na segunda metade do século XVII. Richard Ligon, autor de A True and exact history of the island of Barbados (1657), é enfático quanto ao sucesso dos colonos ingleses na região caribenha. O melhoramento moral e material dessas terras - segundo o ponto de vista inglês - só poderia ser obtido com a efetiva ocupação do território. Diferentemente dos espanhóis e portugueses, que se acomodaram com as descobertas de ouro e prata, os ingleses se viram obrigados a extrair dos territórios os frutos desejados com o suor do seu trabalho. Nessa produção escrita, as menções à busca de metais, como ouro, praticamente inexiste; em seu lugar, os autores enfatizam o trabalho do colono e as dificuldades encontradas como elementos que definem e diferenciam a presença inglesa dentre a dos demais povos europeus.

Anos depois, em 1705, Robert Berkeley, governador da Virgínia, em sua History of Virginia, mostra-se preocupado com os rumos da possessão inglesa, cuja sobrevivência estava apoiada excessivamente na plantação de tabaco. Para esse autor, os ingleses deveriam investir em outros produtos, como frutas e lã, evitando a excessiva dependência de um único produto. Tal perspectiva é comungada por outros contemporâneos, que atentam para o desregramento dos hábitos e da moral nas "plantations" de cana de açúcar no Caribe - Jamaica e Barbados - e na Virgínia.

De acordo com os apontamentos de Jack Greene e Catherine Armstrong, a literatura inglesa sobre a América, após a descrição e a avaliação do continente, tende, sobretudo a partir da segunda metade do século XVII, a centrar sua atenção nos territórios caribenhos e nos resultados aí alcançados com o cultivo de cana de açúcar e do tabaco, ambos largamente mantidos pelo uso de mão da obra escrava. Apesar da grande produção de açúcar nas Antilhas, saudada por autores como Ligon, os pareceres positivos não são unânimes entre os colonos; ao contrário, divide-os: alguns, como Ned Edward Ward, alertam para os vícios que se espalham por toda a população da Jamaica, tida como a nova Sodoma. Em seu relato de 1698, Ward apresenta a seu leitor essa região como "O receptáculo de vagabundos, o santuário dos falidos [...]. Tão rico como um hospital, tão perigoso como uma peste, tão quente como o inferno e tão mau como o diabo". (WARD apud JEHLEN,1997, p. 300). 
A identificação de certas regiões caribenhas com a luxúria e a devassidão constitui, a propósito, uma tópica dos relatos ingleses. Em um texto de 1660, intitulado A loving invitation to repentance and Amendment of life, Richard Pinder aconselha aos proprietários de escravos nas Bermudas e em Barbados que não se entreguem aos vícios tão presentes nessas ilhas, assim como não cometam abusos e, por fim, que sejam pacientes com seus servos. Para concluir, ensina que somente com uma conduta moral ilibada a salvação poderia ser alcançada.

[...]. Oh, vós, habitantes desta ilha! Muitos de vocês são ricos, e os pecados de Sodoma são encontrados no meio de vós; plenitude de pão e abundância de ociosidade. Oh, como é que as criaturas de Deus abusam e se destroem para satisfazer sua luxúria? Vocês acham que o senhor não toma conhecimento de todas as suas maldades, e suas práticas não cristãs? Vocês acham que podem escapar da mão do Senhor? [...]. Vocês desperdiçaram um tempo precioso em tumultos, banquetes e embriaguez [...]. (PINDER apud JEHLEN,1997, p. 220).

Passados alguns anos, pois, os êxitos alcançados nas plantations suscitaram críticas e repreensões de colonos e letrados ingleses que estiveram rapidamente no Novo Mundo ou dele tiveram notícias por marinheiros, comerciantes e colonos que tinham regressado ao reino. No que tange aos indígenas, episódios como o massacre em 1622 e a disputa pela ocupação legal das terras geraram inúmeros escritos que, em boa parte, além de pregar a incapacidade dos nativos para o trabalho e para o progresso moral e material, advogavam o seu extermínio, como é o caso de Nathaniel Bacon. $\mathrm{Na}$ representação do cenário americano sob a pena inglesa, as instigantes possibilidades de êxito dividem espaço com a constatação das adversidades derivadas, em grande parte, do caráter do nativo americano. A partir do final do século XVII, no entanto, a produção escrita tende a se concentrar na avaliação e no questionamento do homem e da natureza do Novo Mundo, como acompanharemos a seguir.

A partir do século XVIII, a produção escrita inglesa se concentra na apreensão do Novo Mundo como parte integrante de um "império inglês"; some-se a isso a publicação de obras dedicadas a compreender o lugar da América na escrita da história e as questões filosóficas que permeiam esse processo - tais como a natureza do homem americano - e teremos um breve panorama das temáticas às quais se dedicaram autores de destaque da historiografia setecentista inglesa, como Edmund Burke e William Robertson.

Até esse momento, a literatura legada pelos agentes ingleses - panfletos, relatos de viagem, carta de colonos, peças de teatro, estatutos das companhias de colonização, entre outros - não 
propaga a ideia de um império. Pelo contrário, é com muita hesitação que essa produção advoga um protagonismo inglês na expansão do mundo, razão pela qual o empenho de um homem como Richard Hakluyt ou a atuação de uma Virginia Company ganharam, então, tanto relevo. A bem da verdade, a propagação da noção de um império, entendido como a possessão e tutela de territórios em diferentes regiões do globo, só pode ser detectada na Inglaterra do ocaso do século XVII. ${ }^{8}$

É com a publicação, em 1685, por Nathaniel Crouch, de The English Empire in America que surge, pela primeira vez, o conceito de um domínio inglês sobre lugares e pessoas do Novo Mundo. Atrelada a essa ideia, o estabelecimento de colonos e o monopólio do comércio nessas regiões são tidos como os motores responsáveis pela expansão e fortalecimento do império inglês. Daí, a longa ênfase dada a esses aspectos nos diversos panfletos, folhas avulsas e nas obras que, em linhas gerais, procuram apresentar e definir esse mesmo império. Na verdade, essas narrativas pouco ou nada diferem entre si, ao contrário, inúmeras vezes é possível perceber uma miscelânea que agrega trechos de panfletos ou de obras anteriores que são reunidas e publicadas sob o nome de um missionário ou de um mercador inglês. A emergência dessa literatura no final do século XVII, portanto, acaba por inserir, lenta e sutilmente, os territórios e habitantes dessas possessões da América na história inglesa. Em tal processo, uma das primeiras imagens veiculadas à noção de império está relacionada com a figura do mercador e com o importante papel desempenhado pelas relações comerciais nesse cenário. Em um dos mais populares periódicos de Londres, o The Spectator, Joseph Addison, um dos editores, sentencia:

[...] A natureza certamente nos fornece o necessário da vida, mas o tráfico nos dá uma grande variedade do que é útil e ao mesmo tempo, fornece-nos tudo o que é conveniente e ornamental. Também não é menor a nossa felicidade enquanto apreciamos os mais remotos produtos do Norte e do Sul [...]. Que os nossos olhos são atualizados com os verdes campos da Inglaterra, ao mesmo tempo em que os nossos paladares são festejados com frutos que se levantam entre os trópic os. Por estas razões, não há membros mais úteis em uma comunidade do que comerciantes. Os homens unidos em uma relação mútua de bons ofícios, distribuem os presentes da natureza, encontram trabalho para os pobres, acrescentam riqueza para os ricos e ouro aos reinos [...].O comércio, sem alargar o território britânico deu-nos uma espécie de império adicional: tem multiplicado o número dos ricos, os nossos territórios infinitamente tornaram-se valiosos do que eram antigamente. (ADDISON apud JEHLEN, 1997, p. 954).

Se, por um lado, as atividades comerciais auxiliam na definição do que seja esse império, por outro lado o domínio sobre os mares, no parecer de autores como Crouch, por exemplo, é posto 
como um dos pilares da supremacia inglesa. Compreendida como uma vocação natural entre os súditos da Commonwealth, a participação em viagens marítimas, somada com o exercício do comércio, era, para o missionário John Oldmixon, o melhor e mais fácil meio de garantir um domínio efetivo sobre as possessões no Atlântico.

[...] Não temos nenhuma maneira de transmitir os nossos produtos e manufaturas a não ser pela navegação, o melhor e mais fácil de todas as maneiras, não temos modo de nos fazermos consideráveis no mundo que não seja pelo nosso comércio [...].(OLDMIXON,1708, p. 18).

A partir da publicação de The English Empire in America, um panorama unificado das possessões americanas e suas relações, sobretudo comerciais, com o reino inglês torna-se o fio condutor das narrativas sobre o além-mar, que repetem exaustivamente em seus prefácios ou em suas introduções observações como as que se seguem:

[...] Nossas colônias na América estão tão longe de ser uma perda para nós, que não há mãos no império britânico mais utilmente empregadas para o lucro e glória da Commonwealth. De todo o nosso comércio na América, o do açúcar é o mais valioso, porque é o mais necessário.(OLDMIXON, 1708, p.28).

O Império Britânico na América do Norte tornou-se tão extenso e importante que, presume-se a qualquer tentativa de transmitir uma noção para o público será recebido favoravelmente por todos os ingleses que querem bem ao seu país, pois, sem o conhecimento correto de um país, [...], não é provável que seja dada atenção à defesa e povoamento, e o incentivo ao comércio para torná-lo vantajoso para a nação em geral, bem como para aqueles indivíduos que se aventuram. (ROGERS apud JEHLEN,1997, p. 857).

Grã-Bretanha, um país de manufaturas sem materiais; uma nação sem comércio de commodities para o comércio e uma potência marítima, sem quaisquer lojas navais ou materiais suficientes para a construção de navios não poderia subsistir muito tempo, como um estado independente, sem suas colônias. (WINTERBOTTHAM, 1796, p. 380).

$\mathrm{Na}$ construção da ideia de império, a apresentação das vantagens comerciais obtidas tanto nas colônias do norte da América como nas ilhas do Caribe não era apenas uma questão retórica; múltiplos interesses, que não os puramente comerciais, vinculavam os súditos ingleses - viajantes, exploradores, poetas, aventureiros, etc. - ao cenário americano. 
Os interesses comerciais tinham, é claro, peso nesta produção, que também não deixava de especular sobre as possibilidades de exploração dos produtos botânicos e minerais dos locais descritos. Tal temática, porém, tendeu a ganhar cada vez mais interesse nas narrativas, a ponto de sociedades e associações científicas organizarem explorações com essa finalidade. Basta citar que, desde 1665, a Royal Society publicava um jornal científico denominado Philosophical Transactions que, por intermédio de seus membros e fellows em diversas partes da Europa e do Novo Mundo, divulgavam temáticas referentes a botânica, história, filosofia natural, matemática, medicina, astronomia, biologia, mineralogia, enfim, um amplo leque de assuntos que visavam a suprir e superar a ausência e inexatidão do conhecimento sobre o mundo americano.

Quanto ao comércio e ao peso conferido a ele, não podemos nos esquecer de que, mais do que apresentar ao público e encorajá-lo a investir nessa atividade, as considerações postas nessas publicações se revestem de um caráter prático, ou seja, os valores e as estatísticas divulgados auxiliavam na avaliação das relações comerciais, temática de considerável importância para o leitor inglês, como esclarece Bryan Edwards em sua obra de 1793:

O leitor da história moderna, sem dúvida, deve considerar a ilhas das Índias Ocidentais, a sua descoberta, suas produções e seu progresso como investigações não negligenciáveis e para o economista, é importante aprender sobre a natureza e a extensão do nosso comércio em uma parte tão célebre dos domínios britânicos. (EDWARDS,1807, p. 15).

Apresentar e narrar a história da ocupação e dos investimentos nas colônias da América do Norte e do Caribe é, para os ingleses, antes de tudo, um objeto de estudo que, em última instância, permitirá um melhor aproveitamento da colonização para todo o império. Aqui, a descrição das atividades dos colonos, dos resultados obtidos, dos empecilhos encontrados, tudo isso é tema de discussão do outro lado do Atlântico. Periodistas, escritores de teatro, mercadores, membros de companhias de migração, entre tantos outros grupos, veem parte do Novo Mundo como uma peça fundamental para o progresso de suas sociedades. Em suma, o Atlântico desponta como o protagonista, no decorrer do século XVIII, entre os ingleses.

Objeto de interesse comercial, mas não somente, o estudo da natureza humana também atrai a atenção de viajantes, missionários, filósofos e historiadores de língua inglesa, como William Robertson ou Bryan Edwards, autores que, em diferentes momentos, lançaram questões sobre o mundo americano. Dentre elas, a origem das populações autóctones despertou amplo interesse. 
Acompanhemos o caso das populações nativas do Caribe, identificadas de imediato com as práticas canibais. Em sua The History civil and commercial of the British Colonies in the West Indies (1793), Bryan Edwards salienta as diferenças entre os habitantes nativos do Caribe: de um lado, os leewards, "povos simples e hospitaleiros", do outro, os caraỉes, "uma bárbara e bélica nação, uma raça de canibais [...] responsável pela devastação onde quer que esteja". Sem mais delongas, Edwards encerra seu parecer num confronto com os filósofos do período, que negavam a veracidade das informações de cronistas e viajantes acerca da existência de canibais.

Esse fato, tão desagradável, foi negado por aqueles filósofos que zelosos em manter a dignidade da natureza impediram a veracidade de todos aqueles que afirmaram a descoberta de canibais. Ao contemplar esta circunstância em suas maneiras, não podemos considerá-los como seres humanos, mas como monstros para quem era legal extirpar a existência. (EDWARDS,1807, p. 11).

Pouco antes, em 1708, na obra de John Oldmixon há um parecer semelhante, que advoga a inabilidade e, portanto, a incapacidade dos nativos de realizarem qualquer atividade comercial, já que "os habitantes dessa ilha nunca foram grande comerciantes. Eles se contentam com o que a terra fornece para a subsistência e encontram o suficiente para a alimentação". (OLDMIXON, 1708, p.447).

No trecho acima, os autores recuperam boa parte dos argumentos usados pelos primeiros colonos que se fixaram tanto na região caribenha quanto ao longo da baía de Cheasepeake para justificar os conflitos e o extermínio das populações autóctones. Esse argumento - que se transforma em uma constante nesses escritos - pautar-se-á, também, pela ideia de que o não aproveitamento das terras, somado ao caráter selvagem e, portanto, não condizente com a natureza humana de seus habitantes, conduz à legalidade da ação e da presença dos súditos do reino inglês nas possessões.

Indagar sobre essa questão não era apenas um simples exercício de deleite filosófico, ao contrário, estava em jogo não apenas como escrever a história moderna europeia - e, nesse caso, como integrar o Novo Mundo às antigas tradições -, mas também a noção de que, para o desenvolvimento do império, era necessário mais do que alguns colonos espalhados por tais regiões, era necessário usar racionalmente o comércio e a agricultura.

Tais questionamentos e polêmicas passaram a ser alvo de especulação filosófica - no caso inglês - apenas com a publicação, em 1777, da obra The History of America, do escocês William 
Robertson. Antes dele, a produção escrita reitera as observações dos primeiros colonos e viajantes sem a preocupação de indagar sobre questões como a origem do homem americano ou a possibilidade ou não de progresso das Índias Ocidentais. Na sua History of America, Robertson lança as primeiras indagações filosóficas acerca do mundo americano em língua inglesa, as quais serão propagadas nos anos seguintes por autores como William Russell. No decorrer de sua obra, Robertson elabora uma interpretação da América que se apoia, em linhas gerais, em três eixos de discussão: as origens e o papel exercido pelos nativos desde a chegada dos europeus; as atividades comerciais e a promoção do progresso entre os ingleses nas possessões americanas; e, por fim, uma longa especulação comparativa acerca da ação das monarquias espanhola e inglesa no Novo Mundo.

Escrita originalmente com a intenção de narrar a história de todos os estabelecimentos europeus no Novo Mundo, a History of America, de William Robertson, quando foi publicada em 1777 contava com oito livros, todos tendo por objeto de análise os estabelecimentos espanhóis. A conturbada situação política das colônias inglesas o fez publicar, o mais rápido possível, sua narrativa, como declara no prefácio da obra. Ainda reticente quanto ao destino das possessões inglesas, Robertson decide trazer a público suas considerações sobre a porção espanhola da história americana e, para isso, se pauta não somente pela produção cronística e pelos relatos de viagem dos séculos anteriores como conta com a colaboração de pessoas entendidas no tema, como o embaixador português na Grã Bretanha, Luis Pinto de Sousa Coutinho, e Alexander Darlymple, cuja coleção de viagens, declara o escocês, contribuiu para a compreensão de curiosos aspectos e informações sobre o estado das colônias espanholas. Anos mais tarde, o filho de Robertson encontra os manuscritos $^{9}$ referentes às possessões inglesas e publica, em 1796, os livros IX e X, intitulados respectivamente The History of Virginia to the year 1688 e The History of New England to the year 1652.

Um primeiro aspecto que chama a atenção na construção da interpretação filosófica da América é a apresentação das populações nativas e o questionamento acerca de seu lugar no devir da história.

[...] a raça de tais habitantes, tão rudes e indolentes, que nada fizeram para melhorar essas terras, se limitando as vantagens obtidas pela situação e pelo clima. Conforme avançamos nas províncias do norte da América, a natureza mantém o mesmo aspecto desgastado e na proporção que o rigor do clima aumenta, parece mais desolada e terrível. Concluímos que os americanos se apresentam em um 
estágio de sociedade desaproveitado assim como ignorantes em todas as artes necessárias desde quando vistos pelos espanhóis. (ROBERTSON,1812, p. 33).

Para Robertson, os habitantes desses territórios se mostram a tal ponto inertes e passivos em relação a qualquer progresso que nem sequer dominam a natureza; ao contrário, são dominados por ela. Dessa maneira, a atuação dos colonos ingleses em solo americano era tida pelo historiador de origem escocesa como um evento memorável, que rompia com um cenário apático e inaugurava, assim, uma nova época no continente, na qual o modo de viver dos selvagens daria lugar a uma sociedade virtuosa.

Ao redigir os capítulos referentes aos anos iniciais da aventura colonial, o autor da History of America não deixa de relembrar, em tom épico, o pioneirismo inglês na propagação de melhoramentos em terras americanas.

Não é de admirar que os colonos enviados da Europa foram surpreendidos no primeiro contato com o Novo Mundo. Este apareceu mal aproveitado, solitário e pouco atraente. Quando os ingleses começaram a se estabelecer na America, eles denominaram essas regiões sob sua possessão de "the wilderness". Nada além de uma ansiosa expectativa em encontrar minas de ouro impulsionou os espanhóis em penetrar em florestas onde, a cada passo, observaram a extrema diferença entre os traços de uma natureza não cultivada e aquela que adquiriu sob a mão da indústria e da arte. (ROBERTSON, 1812, p. 15).

$\mathrm{Na}$ escrita dessa história, Robertson e os autores posteriores destacam a imperiosa necessidade de promover um melhoramento das novas terras, melhoramento que, por sua vez, se apresenta incompatível com os hábitos e valores das populações nativas, consideradas rudes e de caráter duvidoso. Um dos eixos de reflexão desloca-se, então, da vida dos indígenas - objetos de interesse dos primeiros tempos - para as ações dos colonos, cuja análise era tida como fundamental para a compreensão do futuro desses territórios. Aos colonos, como salientamos, foi concedido o papel de protagonistas na aventura colonial. A superação dos entraves do Novo Mundo só poderia ser alcançada com a presença cada vez maior de colonos que, dotados de um caráter industrioso, não se comportariam como escravos da natureza; ao contrário, se destacariam na promoção do seu progresso material e moral. Em linhas gerais, na interpretação que constroem da história da América, os historiadores de língua inglesa salientam que a natureza americana, prodigiosa em seus recursos, reservava aos europeus a fortuna que suas populações nativas foram incapazes de 
aproveitar. E destacam que, dentre os europeus, os ingleses eram o povo cujas condições mostravam-se as mais favoráveis para o empreendimento; afinal, não eram dotados dos vícios e das falhas de caráter tão comuns a seus rivais ibéricos.

Ao redigir uma história das possessões europeias no Novo Mundo, a busca pela afirmação de uma superioridade inglesa conduz à construção de uma interpretação da atuação espanhola na América que, em última instância, acusava os ibéricos por procederem na contramão do movimento da história. Em vez de espalhar o progresso e a virtude, os súbitos das monarquias ibéricas só foram capazes de promover sentimentos e ações torpes. Eis aqui o segundo eixo de reflexão ao qual Robertson se dedica: a análise da atuação ibérica, notadamente da espanhola, e dos resultados alcançados pelos povos da península na formação do caráter de seus colonos e da paisagem natural de suas colônias.

A incapacidade espanhola no Novo Mundo é colocada em discussão não somente quando o assunto é a conversão ou o uso da mão de obra indígena; a própria produção escrita empreendida pelos espanhóis desde a conquista do Novo Mundo era tida como ilustrativa da debilidade dos seus autores. Colocadas em xeque a partir desse momento, as narrativas produzidas pelos espanhóis, especialmente sobre os impérios astecas e incas isentas de qualquer especulação filosófica, em nada contribuía para o desenvolvimento do conhecimento sobre o local e seus habitantes, uma ambição que passa a ocupar a atenção da historiografia inglesa desse período. Compreender não somente o progresso material e moral dessas sociedades, mas também o desenvolvimento da própria espécie humana, estava entre os objetivos que orientavam a escrita dessas "histórias filosóficas da América". A respeito de tal pretensão, Robertson salienta:

[...] a contemplação da condição e do caráter dos americanos em seu estado original favorece o conhecimento completo das espécies humanas e apresenta-se como um considerável atrativo na história do progresso ao conduzir especulações não menos curiosas e importantes. (ROBERTSON, 1812, p. 54).

A crítica aos espanhóis estende-se à crueldade no trato com os nativos e à incapacidade de convertê-los. Senhores de extensas e ricas porções do território americano, os espanhóis mostravam-se, aos olhos ingleses, incapazes de prover o aprimoramento moral do Novo Mundo; ao contrário, é o enraizamento na América dos vícios de seus rudes e ignotos colonos que parece prevalecer no decorrer de mais de um século de ocupação. Acrescente-se o desrespeito às instruções 
legais - notadamente no tocante à escravidão indígena - e ter-se-á, em linhas gerais, um panorama, sob o ponto de vista inglês, da atuação espanhola no novo continente.

É sobre a avaliação da atuação espanhola que, aos poucos, se constrói uma identidade para a presença inglesa no Novo Mundo, compreendida como um empreendimento zeloso das instruções legais empenhado na conversão dos indígenas e comprometido com o aprimoramento material e moral das possessões americanas. Acrescente-se a isso a superioridade de seus colonos, instruídos nas letras e nas artes, e teremos, na perspectiva de Robertson, os elementos que garantiam em parte o êxito da empreitada inglesa. Exemplar dessa assertiva era o caso constantemente citado de William Penn, fundador da Pensilvânia que, nas palavras do filósofo Edmund Burke, ao se dedicar à construção de uma sociedade pautada pela liberdade civil e religiosa no decorrer do século XVII, "preferiu se aventurar num empreendimento desconhecido a fazer sua própria fortuna". Colônias fundadas sob tais preceitos só poderiam, na avaliação dos filósofos e historiadores ingleses, estar destinadas a um "memorável progresso".

A rivalidade com os espanhóis é estimulada pelas novas descobertas que animaram "um apaixonado desejo de obter a glória da Espanha e conseguir algumas daquelas vantagens esperadas nesse novo campo aberto a atividade nacional", como declara Robertson. Em face dos excessos da atuação espanhola, o autor - assim como boa parte da produção escrita desse período - procura destacar aquilo que julga um diferencial inglês em relação às possessões no Novo Mundo: a condução de um governo e de uma administração pautada por normas e condutas legais - ainda em que pesem as peculiaridades locais -, incumbida de promover o melhoramento moral e material nos territórios ocupados, eis aí o que Robertson define como o espírito inglês no Novo Mundo.

Duas décadas antes da publicação da History, de Robertson, em 1757, Edmund e William Burke redigem An Account of the european settlements in America, obra em dois volumes, na qual alertam para os vícios dos povos ibéricos - tais como a indolência, tida como a responsável pela atmosfera luxuriosa dos estabelecimentos espanhóis e portugueses - e para a pouca atenção dada ao melhoramento desses territórios, um descaso que poderia ser estendido à ausência de uma reflexão filosófica sobre os mesmos territórios. De acordo com Burke, a lentidão em aprimorar as possessões, a frieza e o desdém em relação a elas era parte integrante do caráter não somente dos colonos como da própria Coroa Espanhola.

Os ingleses, ao contrário, preocupados com o aprimoramento de suas colônias, buscaram difundir o refinamento nos costumes, na moral, na arquitetura e nas atividades comerciais. Quanto a 
esse último aspecto, tanto Burke como Robertson expressam diagnósticos que apresentam o Novo Mundo como um ambiente cujas condições naturais só favoreciam o intercâmbio comercial. Em tal cenário, com a construção de algumas benfeitorias, só se poderia esperar êxito e prosperidade.

Sem comparação, a América é aquela parte do mundo a qual é melhor abastecida de água não apenas para a manutenção da vida mas para um vantajoso comércio e para a comunicação com outras regiões [...]. Muitas partes de nossos estabelecimentos estão integradas com rios e riachos navegáveis que os colonos podem dizer, sem exagero, possuir um porto em sua própria casa. (BURKE, 1808, p. 248).

O Novo Mundo é extremamente favorável ao intercâmbio comercial. [...] Em todos os aspectos, a América parece comparável com as outras partes do globo. O golfo do México, que corre entre o norte e o sul da América, pode ser considerado como o mar Mediterrâneo que possibilita o comércio marítimo com todas as regiões produtivas que o cercam. (ROBERTSON, 1812, p. 05).

Os interesses despertados pela posse de territórios tão promissores fez com que Burke redigisse capítulos dedicados à apresentação dos principais portos do Novo Mundo e a descrição dos principais produtos aí comercializados, com destaque para os portos de Acapulco e Vera Cruz, no México, Buenos Aires, na província do Prata, e Salvador e Rio de Janeiro, no Brasil, e concedesse pouca atenção para a história civil ou natural dessas colônias. Seu parecer final, que dispensa críticas não somente às monarquias ibéricas, como também à população nativa, destaca as descobertas e a colonização como elementos que, somados à invenção da imprensa e à Reforma, entre outros fatores, inauguraram uma nova fase da própria história europeia. Aos estabelecimentos ingleses era reservado um futuro promissor, visto o respeito por aquilo que Burke denomina de "lei universal": "o melhor Estado é aquele que obedece a uma lei universal que, em linhas gerais, previne a todos da decadência por meio do empenho em promover e difundir o melhoramento moral e material". Eis aí um elemento apontado, não apenas por Burke, com o intuito de diferenciar a presença inglesa dentre as demais coroas europeias.

Apresentados como desprovidos de qualquer gosto pelas artes, preguiçosos, indolentes e cruéis, os indígenas e os crioulos, cujas origens são discutidas, são considerados "povos irrecuperáveis". Na perspectiva de autores como Robertson, essas populações pouco ou nada podem contribuir para a difusão do tão apregoado ideal de melhoramento.

Como podemos perceber, a History Of America, de Robertson, é uma obra capital da historiografia inglesa desse período, não apenas por sistematizar as questões referentes à América e 
seu lugar na escrita da história, como também por ser a base a partir da qual inúmeros autores, como Snowden e William Russel, por exemplo, se orientaram para compor seus estudos. Ainda que não apresentem nenhum acréscimo em relação à narrativa de Robertson, os textos posteriores auxiliaram nesse processo de compreensão da construção de um lugar para a América na história escrita em língua inglesa. Passemos os olhos por mais um caso, o de William Russel.

Homem erudito, Russel dedicou-se a uma ampla gama de temáticas, produzindo uma série de escritos em prosa e em verso, dois dos quais dedicados à América: uma História da América, de 1778, e um terceiro volume da The History of Modern Europe, de 1784, no qual concede especial atenção aos estabelecimentos coloniais. Aqui não se trata apenas de uma simples alusão à América e a seus territórios, mas da sua incorporação ao processo de compreensão da própria história europeia. Nessas narrativas, o autor apresenta os melhoramentos alcançados pela humanidade no decorrer dos séculos, em um movimento sempre direcionado, nas suas palavras, para o "refinamento das artes e do homem". As descobertas exemplares dessa nova era, para além de promoverem o refinamento dos povos selvagens, promoviam também um "extraordinário" intercâmbio comercial, "que tem feito consideráveis progressos em direção à civilização". Toda a ação inglesa nos territórios da Virgínia e da Nova Inglaterra corroborava essa tese. Semelhante à narrativa de Robertson, a de Russell apresenta uma avaliação histórica da atuação dos povos ibéricos de pesadas cores. Para além da crueldade dos conquistadores e da ignorância dos colonos ibéricos, o autor destaca o caráter corrupto dos portugueses.

Porém como todo povo que repentinamente conquista grandes riquezas, os portugueses começaram a sentir os efeitos da luxúria. Valores elevados que presidem muitas nações já não existem entre eles: dificilmente se enveredam em batalhas, exceto quando há a possibilidade de pilhagem. A corrupção prevalece no governo e o espírito de rapina entre todos os homens. (RUSSELL,1822, p.176).

Em suma, Russell reitera as observações e comentários de autores dos séculos anteriores que postulam a completa incapacidade dos povos ibéricos em difundir ideais nobres e em construir uma sociedade pautada nas sanções legais e no sucesso individual de seus habitantes. Tal como os autores que o antecederam, o texto de Russell centraliza sua análise na crença do aprimoramento moral da América, um aprimoramento ditado pelas leis da história e que estava intrinsecamente ligado à participação inglesa na colonização, segundo a interpretação histórica construída lentamente no decorrer do século XVIII. 


\section{Referências Bibliográficas \\ Documentação}

BRADFORD, William. History of Plymouth Plantation. Nova York: Charles Sons, 1908.

BERKELEY, Robert. History and Present State of Virginia. Londres: Parker,1705.

BURKE, Edmund. An account of the european settlements in America. Containing an accurate description of their extent, climate, poductions, trade, genius and dispositions of their inhabitants, the interests of the several powers of Europe, with respect to those settlements and their political and commercial views with regard to each other. Londres: J.J. Stockdalls, 1808.

CROUCH, Nathaniel. The English Empire in America. Or a Prospect of His Majesties Dominions in West Indies. Londres: Crouch, 1685.

EDWARDS, Bryan. The History civil and commercial of the British Colonies in the West Indies, Londres: John Stockdale,1807.

GILBERT, Humprey. Voyage to Newfoundland by Edward Haies. Nova York: Collier and Son Company, 1910.

Gray, Robert. A Good Speed to Virginia. Londres, 1609. Early English Books Online. 2003. Early English Books Online Archive. 1 February 2008. <http:/gateway.proquest.com/openurl?ctx_ver=Z39.88-2003\&rft_id=xri:eebo:image:6158>

HAKLUYT, Richard. Discourse of Western Planting. Cambridge: Press of John and Wilson Son, 1877.

The principal navigations, voyages, trafiques and discoveries of the English people,. Londres: Richard Hakluyt Society, 1907.

HUBBARD, William. A General History of New England. Boston: Charles Little and James Brown, 1848.

OLDMIXON, John. The British Empire in America. Containing the history of the discovery, settlement, progress and present state of all the british colonies on the continent and islands of America. Londres: John Nicholson/Benjamim Tooker, 1708.

PURCHAS, Samuel. Hakluytus Posthumus or Purchas his pilgrimes. Glasgow: Hakluyt Society, 1907-1910, 4v.

RALEIGH, Walter. The Discovery of the large, rich, and beautiful Empire of Guiana. Londres: Richard Hakluyt Society, 1848.

ROBERTSON, William.The History of America. Londres: Strahall/Caden,1812. 
RUSSELL, William. History of Modern Europe. With an account of the decline and fall of the Roman Empire and a view of the progress of society. Philadelphia: Abraham Small,1822.

SMITH, John. A true relation of such occurences and accidents of note as hath happened in Virginia. Since the first planting of that colony which is now resident in the South part thereof till the last return from thence. Wrtitten by Captain Smith, one of the said colony to a worshipful friend of his in England Richmond. Boston: Whiggin/Lunt,1866.

WINTERBOTHAM, William. An historical, geographical commercial and philosophical View of American United States and the European Settlement in America and West Indies. Nova York: Tiebout/O’Brien, 1796.

\section{Estudos}

ARMSTRONG,Catherine(ed). America in the british imagination. Cambridge: Cambridge Publishing, 2007. . Writing North America in Seventeenth Century.Hampshire: Ashgate, 2007.

CANIZARES-ESGUERRA, Jorge. How to write the history of the New World: histories, epistemologies and identities in the Eighteenth Century Atlantic Wold. Stanford: Stanford U. Press, 2001.

GREENE, Jack P. Reformulando a identidade inglesa na América Britânica colonial: adaptação cultural e experiência provincial na construção de identidades corporativas. In Almanack Braziliense, n.4, Nov.2006.

Pursuits of Happiness. The social development of early modern british colonies and the formation of American culture. Chapel Hill/ NC: University of North Carolina, 1988.

. The intellectual construction of the America. Exceptionalism and Identity from 1492 to 1800. Chapell Hill: University of North Carolina Press, 1993.

Press, 2009.

; MORGAN, Phillip. (ed). Atlantic History: a critical appraisal. Oxford: Oxford University

By their laws shall ye know them: law and identity in Colonial British America. Journal of Interdisciplinary History, 33 (Autumn 2002).

JEHLEN, Myra; WARNER, Michael. (ed). The English Literatures of America. Nova York/Londres: Routledge, 1997.

MANCALL, Peter. Hakluyt's Promise: An Elizabethan's Obsession for an English America. Londres/New Haven: Yale University Press, 2007. 
PAGDEN, Anthony. The struggle for legitimacy and the image of Empire in the Atlantic to c. 1700. In: CANNY, Nicholas. (ed). The Oxford History of the British Empire. Oxford: Oxford University Press, vol I.

\section{Notas}

${ }^{1}$ De acordo com Jack Greene, essa literatura "se concentrava muito na descrição dos espaços físicos que dada colônia viria a ocupar e na formulação de propostas para um uso eficiente desse espaço. [...]. Especulavam sobre que produtos então em demanda do lado oriental do Atlântico poderiam ser lá cultivados e imaginavam como aquele espaço físico específico poderia ser adaptado aos desígnios ingleses". (Cf. GREENE In Almanack Braziliense, n.4, Nov.2006, p.12.)

2 Tal característica será apontada pelos autores do século XVIII como um elemento de distinção da atuação inglesa no Novo Mundo. O historiador Anthony Pagden observa que "confusedly at first and then with religious, and invariably self-righteous zeal, they abandoned the vision of El Dorado and Spanish-style kingdoms overseas for that of 'colonies' and 'plantations' places, that is, which would be sources not of human or mineral but of agricultural and commercial wealth". (Cf. PAGDEN In: CANNY, vol I, p.36.)

${ }^{3}$ Essa região corresponde atualmente à costa nordeste do Canadá.

${ }^{4}$ Essa se constituirá em um dos tópicos da produção escrita inglesa desse período, em outras palavras, a afirmação do direito inglês de tomar posse desses territórios.

${ }_{6}^{5}$ Corres ponde atualmente à costa venezuelana.

${ }^{6}$ Acusado no reinado de Jaime I de planejar uma conspiração, Raleigh foi condenado a treze anos de prisão, entre 1603 e1616, período no qual redigiu a obra History of the World.

${ }^{7}$ Cabe notar que não somente a produção em língua inglesa dos séculos XVIII elaborada principalmente por autores de origem escoces a fará largo uso dessas ideias como também a própria percepção da historiografia dos e sobre os Estados Unidos, por meio do conceito de "american exceptionalism". (Cf. GREENE, 1993.)

${ }^{8}$ Anteriormente, como esclarece o historiador Nicholas Canny, a palavra império era usada com uma conotação muito peculiar, sempre ligada à ideia de uma longa tradição inglesa de independência e autonomia frente a potentados estrangeiros, ou seja, esse conceito tem, nos séculos XVI e parte do XVII, mais relação com certo isolamento in glês diante dos demais reinos do que com uma possível supremacia sobre estes.

${ }^{9}$ Os apontamentos acerca das possessões portuguesas, de acordo com Robertson, seriam publicados emum volume à parte; no entanto, nada se sabe acerca do destino dos manuscritos.

Recebido em agosto de 2011.

Aprovado em março de 2012. 